\title{
Protein adsorption to hydrocephalus shunt catheters: CSF protein adsorption
}

\begin{abstract}
Howard L Brydon, Geoff Keir, Edward J Thompson, Roger Bayston, Richard Hayward, William Harkness
\end{abstract}

the valve components, peritoneal malabsorption, ${ }^{145}$ and protein deposition obstructing the shunt lumen. ${ }^{16}$ We have recently investigated the first two mechanisms, and neither has been supported: protein had an insignificant effect on CSF viscosity, ${ }^{7}$ and the surface tension of CSF, which affects valve sticking, was lower when more protein was present. $^{8}$ These findings have also been supported by an in vitro study on the perfusion of shunts with protein solutions.

The adsorption of CSF proteins on to shunts has not yet been studied. The aim of this project was therefore to determine the extent to which proteins accumulated on the catheter wall, and to ascertain whether this could cause catheter obstruction. In addition, a qualitative assessment of the nature of the proteins was undertaken.

The standard shunt used at Great Ormond Street Hospital for Children is the CordisHakim system (Cordis UK, Brentford, Middlesex, UK), which consists of an integral valve and distal catheter. The whole shunt is often replaced during revision operations, and so a large amount of catheter material was available for study.

Keywords: hydrocephalus shunts; cerebrospinal fluid protein; silicone rubber; protein adsorption

Mr HL Brydon, Department of Neurosurgery, Queen

Elizabeth Hospital, Metchley

Lane, Birmingham B15

2TH, UK.

Received 1 October 1996 and in revised form 10 October 1997

Accepted 20 October 1997

It is a common belief that a high CSF protein concentration impairs hydrocephalus shunt performance. There are several mechanisms that could cause this-for example, reduced flow due to high CSF viscosity, ${ }^{1-3}$ sticking of

Table 1 Original diagnosis of patients whose explanted catheters were analysed

\begin{tabular}{lcccc}
\hline Diagnosis & $\begin{array}{l}\text { Proximal } \\
\text { catheter }\end{array}$ & $\begin{array}{l}\text { Distal } \\
\text { catheter }\end{array}$ & $\begin{array}{l}\text { Ventricular } \\
\text { drain }\end{array}$ & Total \\
\hline Idiopathic hydrocephalus & 15 & 7 & 2 & 24 \\
Posthaemorrhagic hydrocephalus & 12 & 13 & 4 & 29 \\
CNS malformation & 5 & 11 & 4 & 20 \\
Tumour & 3 & 5 & 1 & 9 \\
Postinfective hydrocephalus & 2 & 6 & 4 & 12 \\
Unknown & 4 & 3 & 1 & 8 \\
Total & 41 & 45 & 16 & 102 \\
\hline
\end{tabular}

Table 2 Indications for removal of the catheters compared to the mean duration of implantation

\begin{tabular}{|c|c|c|c|c|}
\hline \multirow[b]{2}{*}{ Indication for removal } & \multicolumn{2}{|c|}{ Proximal catheters } & \multicolumn{2}{|c|}{ Distal catheters } \\
\hline & $n$ & Mean time (months) & $n$ & $\begin{array}{l}\text { Mean time } \\
\text { (months) }\end{array}$ \\
\hline Infection & 9 & 0.8 & 13 & 2.5 \\
\hline Upper obstruction & 14 & 11.0 & 6 & 4.0 \\
\hline Valve obstruction & 4 & 27.9 & 6 & 45.1 \\
\hline Lower obstruction & 3 & 26.8 & 8 & 41.6 \\
\hline Disconnection/ migration & 1 & 86.8 & 5 & 102.8 \\
\hline Overdrainage & 4 & 43.8 & 4 & 27.5 \\
\hline Pain & 0 & & 2 & 132.8 \\
\hline Elective removal & 0 & & 1 & 1.0 \\
\hline
\end{tabular}

\section{Materials and methods}

PATIENTS

Eighty six permanent catheters replaced during shunt revisions were collected prospectively from 49 patients over a 15 month period (table $1)$ : in 20 cases proximal and distal catheters were obtained from the same shunt. In addition, 16 temporary ventricular drains were collected and analysed.

Table 1 shows the patients' original diagnoses. The mean implant time for the ventricular catheters was 25.3 months and for peritoneal catheters 34.3 months. However, this varied with the reason for removal (table 2). Most ventricular drains had been inserted for shunt infections, and they had been in situ for a mean of 10 days (range three to 15 days).

ANALYSIS

The CSF within the catheter was aspirated, examined by light microscopy, and then cultured bacteriologically. ${ }^{10} \mathrm{~A} 1 \mathrm{~cm}$ length of catheter was prepared and examined by scanning electron microscopy. ${ }^{11}$ Adsorbed proteins were eluted from the remainder of the catheters using $0.9 \%$ saline followed by a solution of $0.5 \%$ 3-((3-cholamidopropyl)-dimethylammonio)-1propanesulphonate (CHAPS; BDH Chemicals, Dagenham, UK) in barbitone electrophoresis buffer ( $\mathrm{pH}$ 8.6). ${ }^{12}$ CHAPS was chosen as it is 


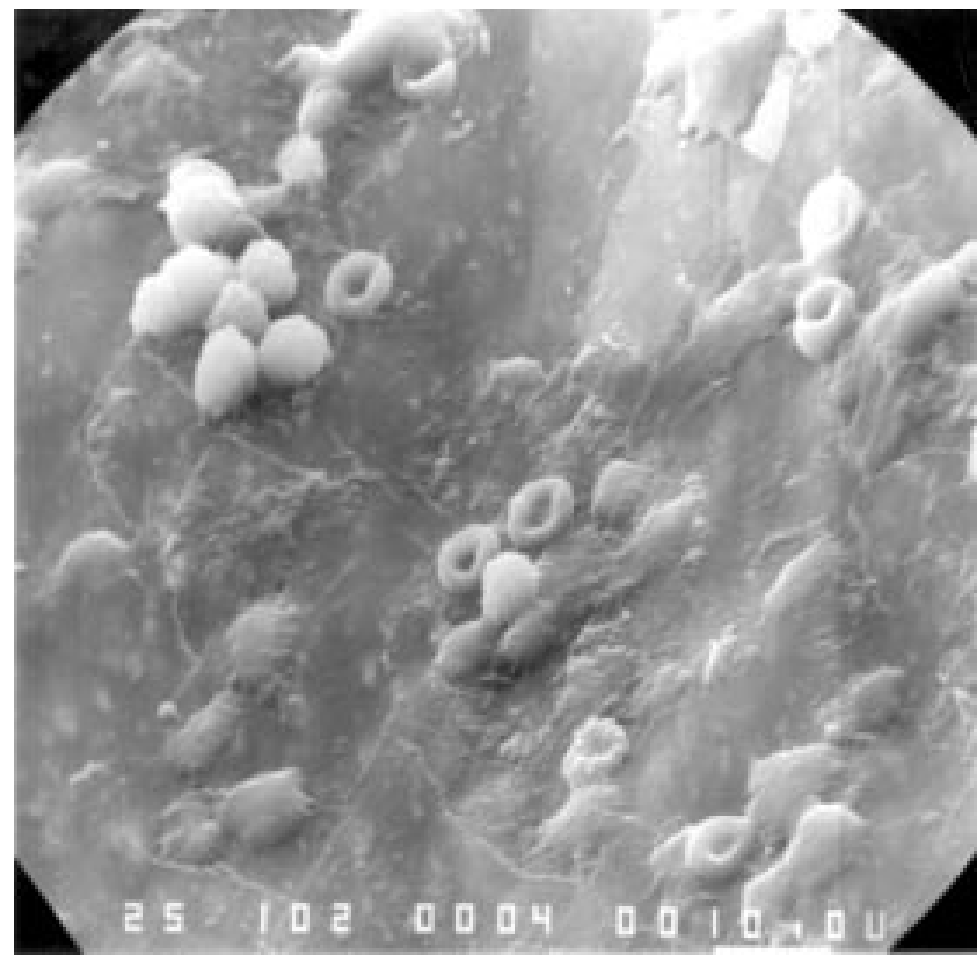

Figure 1 Originally $\times 1000$. Peritoneal catheter removed after 10 days for infection. Bacteria were not found, but many red and white blood cells were present on the shunt surface. A surface biofilm was also evident from the places where it has cracked during processing.

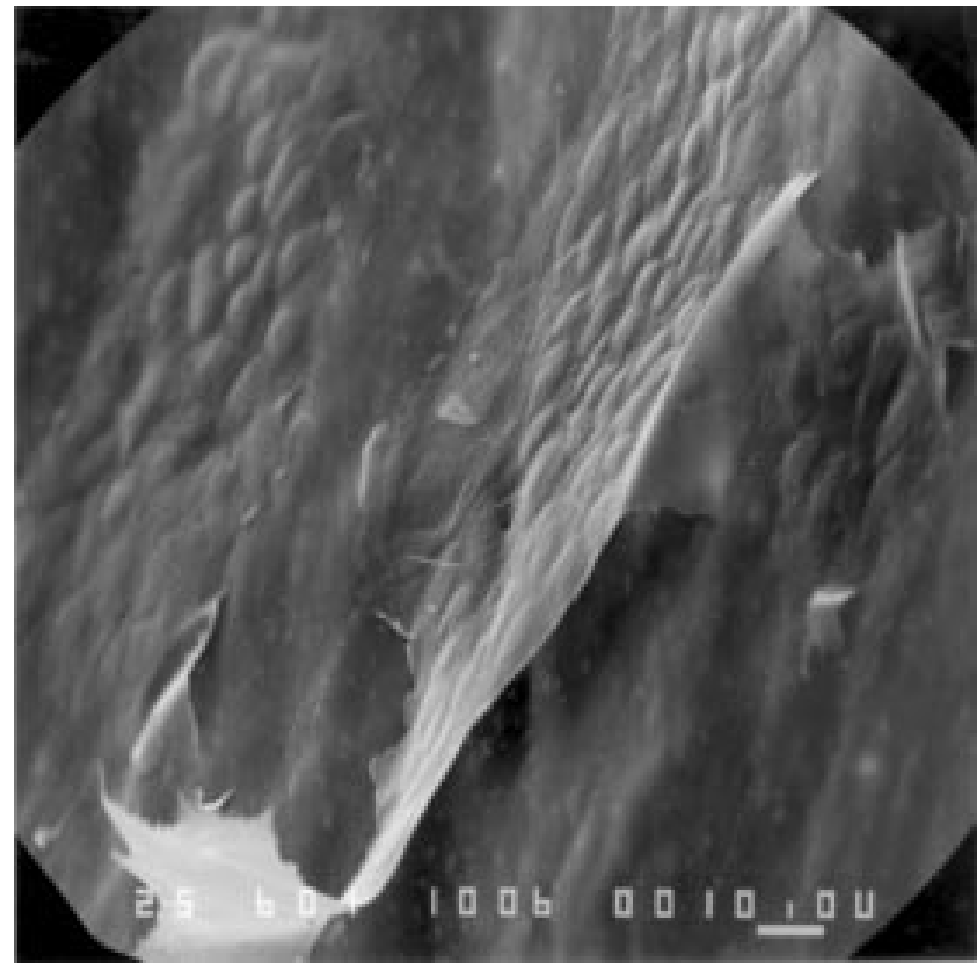

Figure 2 Originally $\times 600$. Same specimen as figure 1. The biofilm has been partly detached during processing. The quilted appearance suggests that it has been derived from degenerating cells. stored separately at $-20^{\circ} \mathrm{C}$. Longer periods of elution (up to 72 hours) did not increase the yield of protein.

Attempts were made at measuring the total protein content of the eluate by protein precipitation using benzethonium chloride. ${ }^{13}$ Electrophoresis of the eluate $(5 \mu$ l volume $)$ was performed on agarose gel (FMC Bioproducts, Vallenbaek Strand, Denmark). ${ }^{12}$ The proteins were blotted on to nitrocellulose (Sartorius AG, Goettingen, Germany), ${ }^{12}$ and stained with gold chloride. ${ }^{14}$ Electrophoresis of the patients' $\mathrm{CSF}$ was also performed using $2 \mu \mathrm{l}$ volumes.

\section{Results}

Choroid plexus was the cause of six ventricular catheter obstructions. Another four ventricular catheters had been replaced because of malposition or disconnection. No cause for the shunt obstruction could be found in the part considered peroperatively at fault in 15 cases (eight ventricular and seven peritoneal catheters), although in seven of them the shunt valve was obstructed. The valves were subjected to a different (mechanical) analysis. ${ }^{15}$ In the other cases we think that the obstructive material was wiped off the shunt during its removal, although it is possible that we did not receive the part of the shunt containing the obstruction.

One peritoneal catheter was obstructed by granulation tissue growing from the outside through a hole in the wall of the catheter. This hole looked as if it had been made during insertion of the shunt, which had been implanted for 73 months. The shunt had not been infected, and the patient had normal CSF.

In no instance had sufficient protein precipitated within a catheter to obstruct it. Furthermore, scanning electron microscopy did not show a microscopic focal protein accumulation on any catheter, although a thin film was present on $15 \%$ of catheters. This was noticeable only where it had cracked during processing, and so might have been unnoticed on others (figs 1 and 2). Red and white blood cells were found on the surface of seven catheters (fig 1), degenerating cells on seven, and bacteria on four specimens. Bacteria were grown from 10 catheters removed for presumed infection, and microscopy also disclosed degenerating cell debris in these catheters.

The protein content of the shunt eluate was too low to measure $(<0.01 \mathrm{~g} / \mathrm{l})$, even though 20 catheters were from patients with a CSF protein concentration $>1.0 \mathrm{~g} / \mathrm{l}$ (range 0.06$12.3 \mathrm{~g} / \mathrm{l}$, mean $1.06 \mathrm{~g} / \mathrm{l}$, median $0.32 \mathrm{~g} / \mathrm{l}$ ). Nevertheless, protein bands were identified on electrophoresis of all 102 specimens. Albumin was identified in all specimens, and in 18 $(18 \%)$ this was the only significant band identified, the rest of the trace being too faint. A $\gamma$-globulin band was identified in 70 specimens $(70 \%)$ and transferrin in $61(61 \%)$. Haptoglobin was identified in $28(28 \%)$ and tau-protein (asialtotransferrin, tau-transferrin) in $13(13 \%)$. A full electrophoretic sequence, similar to CSF, was found in only $13 \%$ (fig 3 ). 


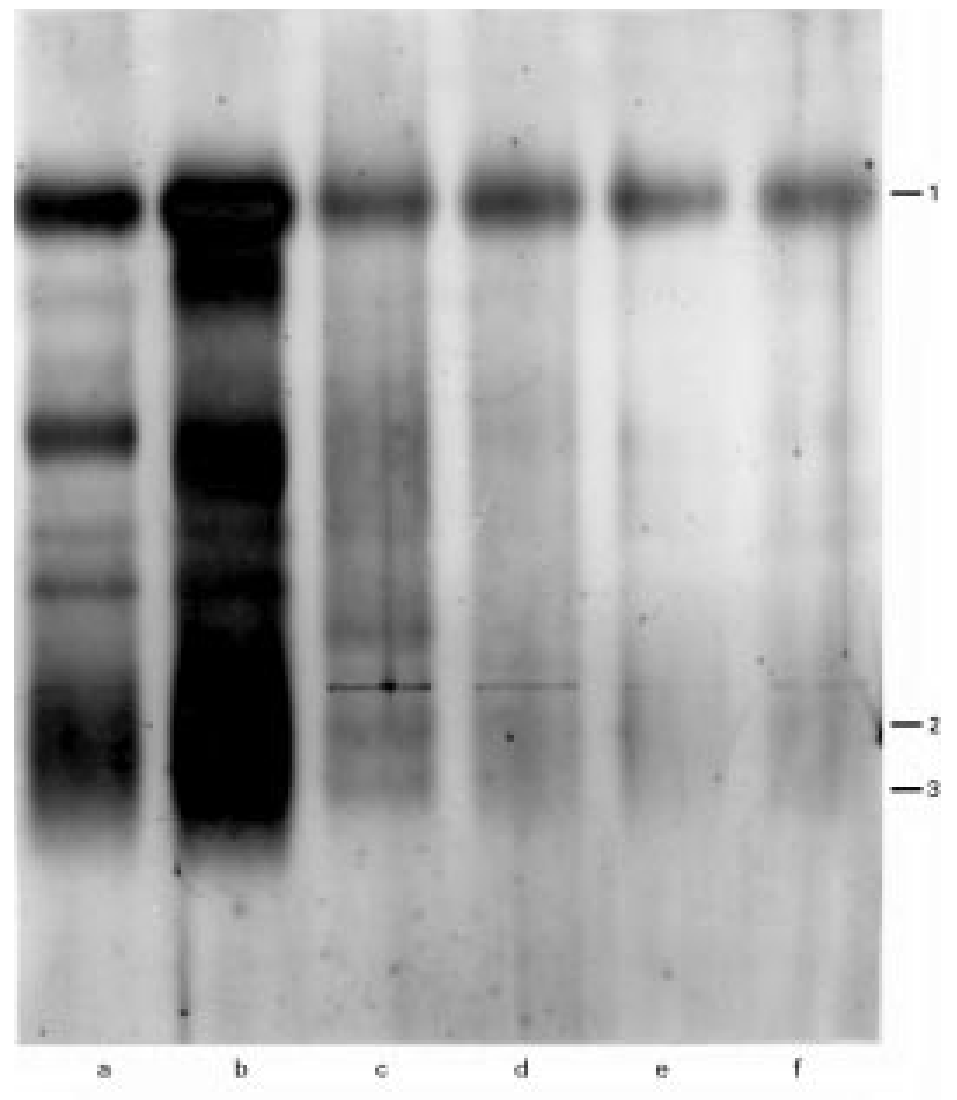

Figure 3 Electrophoresis of specimens from a patient undergoing a shunt revision for disconnection after 28 months. (a) Serum, 1:500 dilution; (b) CSF; (c) ventricular catheter eluate with $0.9 \%$ saline; (d) ventricular catheter eluate with $0.5 \%$ CHAPS. Prealbumin is only visible in specimen d. Albumin is in position 1, and the two unidentified $\gamma$ region bands in positions 2 and 3 .

In 44 specimens (44\%), two distinct bands were identified in the $\gamma$ region on elution with both saline and CHAPS (figs 3 and 4). However, western blotting ${ }^{16}$ for IgG, IgM, IgA, fibrinogen, and fibronectin all proved negative. These bands were identified in ventricular and peritoneal catheters and ventricular drain specimens. They were found in catheters that had been implanted for a few days as well as for several years. Furthermore, they were not associated with any specific cause of shunt failure, being found in catheters removed for infection, overdrainage, disconnection, and obstruction. It was noted that the fraction did not store well, and on repeated electrophoresis the bands were fainter. This prevented the pooling of positive specimens for protein sequencing.

\section{Discussion}

Shunts are the standard treatment for hydrocephalus, but they are prone to complications, with up to $16 \%$ of shunts requiring revision within one month. ${ }^{17}$ Some consider that a high CSF protein plays a part in shunt failure, ${ }^{1-6}$ but recent work has invalidated most theories on possible mechanisms. ${ }^{7-9}$ However, the possibility of protein deposition obstructing the shunt lumen has not yet been investigated.

In 1963 Scarff stated that "...cerebrospinal fluid is laden with protein and minerals, which are gradually deposited as particulate matter on the inner surfaces of the tubes and valves, contributing to their obstruction or malfunction" ${ }^{6}$ This statement, from a clinical review, was made without any supporting evidence, but is still accepted by many. Furthermore, as far as can be determined, no attempt has been made to verify or refute the statement.

The only material present in sufficient quantities to occlude the catheters in this series was choroid plexus. Several authors, analysing material found in shunt catheters by light microscopy, have reported that "fibrin", "protein" and leucocytes have been the cause of shunt obstructions. ${ }^{18-20}$ However, they did not state whether biochemical analysis was performed to confirm the identity of the materials, nor where the presumed "fibrin" originated, as clotting proteins are normally absent from CSF. ${ }^{21} 22$ Furthermore, the composition of the patients' CSF was not given. Bacterial slime is strand-like, ${ }^{11}{ }^{23}$ and might be confused with fibrin on microscopy.

Snow and Kossovsky ${ }^{24}$ found a cylindrical core of tissue, up to $8 \mathrm{~mm}$ long, in $51 \%$ of the 57 shunts they examined. This tissue was always at the end of the catheters, and on microscopy consisted a combination of blood, fibrous tissue, neural tissue, and inflammatory tissue (sterile or infective). Similar tissues have been detected by others, but not in sufficient amounts to cause obstruction. ${ }^{20}$ The pathogenesis of these intralumenal tissues has not been speculated on, but there is nothing to suggest that they were related to a high CSF protein content. Material from the surgical team, or patient, including cotton, talc, and hair have also been found inside shunts. ${ }^{20}$

The amount of protein that we could remove from the catheters was too small to assay, but a large amount of soluble protein would not be expected if most of the debris were of cellular origin. ${ }^{15}$ It should be noted that plasma contains essentially the same proteins as CSF, but in a 500-fold greater concentration, and yet shows no tendency to precipitation. Therefore, the accumulation of large amounts of CSF protein within shunt catheters should not be expected.

It could be argued that as protein adsorption is a dynamic process, more protein might have been adsorbed onto the catheters at times when the CSF protein concentration was higher, and as the CSF protein concentration fell, the amount of adsorbed protein also became less. However, our results from the ventricular drains, which were in situ for a few days only, were no different from those of the other catheters, which had been in situ for much longer. Furthermore, the ventricular drains were inserted when the CSF protein was often higher. In addition, other work has indicated that the CSF protein concentration of patients who developed early shunt obstructions was not significantly higher than of the other patients. $^{26}$

There remains the possibility that not all of the adsorbed protein was removed, but scanning electron microscopy only disclosed a thin biofilm on the catheters, and further suggested that it might be derived from degenerating 


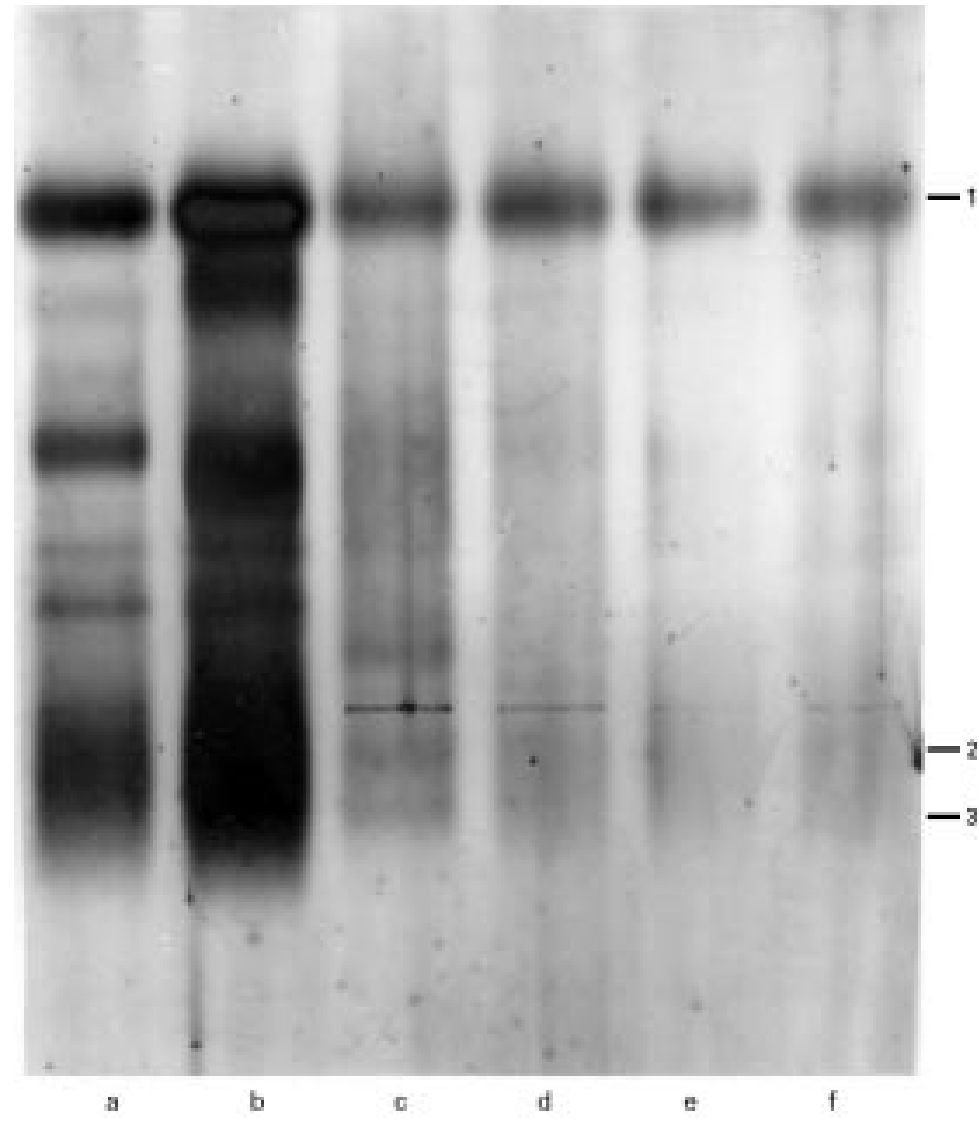

Figure 4 Electrophoresis of specimens from a patient who had a shunt revision for infection after 10 days. (a) Serum, 1:500 dilution; (b) CSF; (c) ventricular catheter eluate with $0.9 \%$ saline; (d) ventricular catheter eluate with $0.5 \%$ CHAPS; (e) peritoneal catheter eluate with $0.9 \%$ saline; $(f)$ peritoneal catheter eluate with $0.5 \%$ CHAPS.

Prealbumin is not visible. Albumin is in position 1, and the two unidentified $\gamma$ region bands in positions 2 and 3. They are only visible in the ventricular catheter eluate (specimens $c$ and d), and not in the peritoneal catheter eluate (specimens e and f).

cells. Other groups that have studied protein adsorption in vitro $^{27}$ and in vivo $^{28}$ have presented qualitative results only. Methods to quantify protein adsorption have usually involved the use of radiolabelled protein in vitro.

Protein adsorption to polymers is considered by some to continue for several hours after exposure, ${ }^{29}$ but others consider that it is at a maximum by 30 minutes. $^{30}$ It is thought that successive layers are formed, and that the protein in the outermost (lumenal) layer is in dynamic equilibrium with the protein in solution, whereas the protein adjacent to the catheter wall is firmly adherent. Several mechanisms, including hydrogen bonding, ionic interaction, and calcium bridges between carboxyl groups, are thought to be involved in the adsorption process. ${ }^{29}$ Long term consolidation of the adsorbed protein is also considered a possibility.

One group ${ }^{29}$ found that the total amount of protein that adsorbed to silicone rubber was 74 $\mu \mathrm{g} / \mathrm{cm}^{2}$ at two hours, using a $20 \mathrm{mg} / 1$ albumin and fibrinogen solution. This is equivalent to protein absorption on to the inner surface of a shunt catheter at a rate of $30 \mu \mathrm{g} / \mathrm{cm}$, which is far too small to obstruct it. Another group ${ }^{31}$ measured the amount of adsorbed protein at only $2 \%$ of this value, using a different polymer and technique. ${ }^{29}$
Several workers have reported that albumin adsorbs the most to hydrophobic catheters, although $\gamma$-globulin also adsorbs to a significant degree. ${ }^{27} 28{ }^{32}$ Clotting proteins, if present, also adsorb preferentially to the polymer. In this study, albumin was detected on all catheters, and so this agrees with the published work. The adsorption of albumin is advantageous, as it improves the biocompatibility of silicone rubber and inhibits bacterial adhesion, which should help prevent shunt colonisation..$^{33-37}$

The identity of the two $\gamma$ region bands was not confirmed. They might be previously unrecognised CSF constituents that had accumulated on the catheters, or might be breakdown products of a more common protein fraction. A bacterial origin is unlikely as they were present on both non-infected and infected catheters. Although their nature remains unknown, their low concentration would suggest that they are unlikely to be relevant in shunt malfunction.

\section{Conclusions}

We have been unable to show that protein accumulates on shunt catheters in sufficient amounts to cause obstruction, although a thin film is formed. The major protein in this film is albumin, and other studies have shown that this will improve the biocompatibility of the silicone rubber. ${ }^{37}$

We thank the Datnow family and the Wade Charitable Trust for financial assistance with this project.

1 Occhipinti E, Carapella CM. Shunt failure in hydrocephalus with high protein fluid. Monographs in Neural Science 1982;8:220-2.

2 Salmon JH. A ventriculoperitoneal shunt for hemorrhagic or high protein fluid. Surg Neurol 1977;8:69-70.

3 Schachter P, Findler G. Continuous spinal drainage of high viscosity CSF using IVAC system-technical note. Acta Neurochir (Wein) 1987;84:71-2.

4 Adegbite AB, Khan M. Role of protein content in CSF ascites following ventriculoperitoneal shunting. $\mathcal{F}$ Neurosurg 1982;57:423-5.

5 Yount RA, Glazier MC, Mealey J, et al. Cerebrospinal fluid ascites complicating ventriculoperitoneal shunting. Report of four cases. $\mathcal{F}$ Neurosurg 1984;61:180-3.

6 Scarff JE. Treatment of hydrocephalus: an historical and critical review of methods and results. $\mathcal{F}$ Neurol Neurosurg Psychiatry 1963;26:1-26.

7 Brydon HL, Bayston R, Hayward R, et al. Physical properties of cerebrospinal fluid of relevance to shunt function. 1: The effect of protein upon CSF viscosity. $\mathrm{Br} \mathcal{F ~ N e u -}$ rosurg 1995;9:639-44.

8 Brydon HL, Bayston R, Hayward R, et al. Physical properties of cerebrospinal fluid of relevance to shunt function. 2: The effect of protein upon CSF surface tension and contact angle. Br F Neurosurg 1995;9:645-51.

9 Brydon HL, Hayward R, Harkness W, et al. The effect of protein and blood cells on the flow-pressure characteristics of shunts. Neurosurgery 1996;38:498-505.

10 Bayston R, Leung TSM, Wilkins BM, et al. Bacteriological examination of removed cerebrospinal fluid shunts. $\mathcal{F}$ Clin Pathol 1983;36:987-90.

11 Bayston R. A model of catheter colonisation in vitro and its relationship to clinical catheter infections. F Infect 1984;9: 271-6.

12 Jeppsson JO, Laurell CB, Franzén B. Agarose gel electrophoresis. Clin Chem 1979;25:629-38.

13 Luxton RW, Patel P, Keir G, et al. A micro-method for measuring total protein in cerebrospinal fluid by using benzethonium chloride in microtitre plate wells. Clin Chem 1989;35:1731-4.

14 Keir G, Thompson EJ. Ultrasensitive staining of proteins after agarose electrophoresis of unconcentrated cerebrospinal fluid. Ann Clin Biochem 1988;25:116-7.

15 Brydon HL, Bayston R, Hayward R, et al. Explanted shunt valves: reasons for failure and implications for valve design. vrf Neurosurg 1996;10:245-52.

16 Towbin H, Staehelin T, Gordon J. Electrophoretic transfer of proteins from poylacrylamide gels to nitrocellulose sheets: procedure and some applications. Proc Natl Acad Sci USA 1979;70:4350-4 
17 Puca A, Anile C, Maria G, et al. Cerebrospinal fluid shunting for hydrocephalus in the adult: factors related to shunt revision. Neurosurgery 1991;29:822-6.

18 Little JR, Rhoton AL, Mellinger JF. Comparison of ventriculoperitoneal and ventriculoatrial shunts for hydrocephalus in children. Mayo Clin Proc 1972;47:396-401.

19 Hakim S. Observations on the physiopathology of the CSF pulse and prevention of ventricular catheter obstruction in
valve shunts. Dev Med Child Neurol 1969;11(suppl 20):42-8.

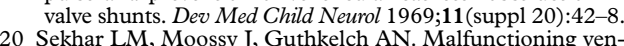
Sekhar LM, Moossy J, Guthkelch AN. Malfunctioning venF Neurosurg 1982;56:411-6.

21 Anderson M, Matthews KB, Stuart J. Coagulation and fibrinolytic activity of cerebrospinal fluid. $\mathcal{f}$ Clin Pathol 1978;31:488-92.

22 Dube RK, Sahaa PK, Dude B, et al. Fibrinogen, fibrinogen degradation products and fibrinolytic activity in cerebros-
pinal fluid in stroke. Indian $\mathcal{7}$ Med Res 1980;72:454-7.

23 Bayston R, Penny SR. Excessive production of mucoid substance in Staphylococcus SIIA: a possible factor in colonistance in Staphylococcus SIIA: a possible factor in coloni-
sation on Holter shunts. Dev Med Child Neurol 1972; 14(suppl 27):25-8.

24 Snow RB, Kossovsky N. Hypersensitivity reaction associated with sterile ventriculoperitoneal shunt malfunction. Surg Neurol 1989;31:209-14

25 Kossovsky N, Snow RB. Clinical-pathological analysis of failed central nervous system fluid shunts. F Biomater Appl 1989;23 (suppl A1):73-86.

26 Brydon HL, Hayward R, Harkness W, et al. Does the cerebrospinal fluid protein concentration increase the risk of shunt complications? Br f Neurosurg 1996;10:267-74.

27 Limber GK, Glenn CH, Mason RG. Studies of the proteins elutable from certain artificial surfaces exposed to human plasma. Thromb Res 1974;5:735-46.

28 Lyman DJ, Metcalf LC, Albo D, et al. The effect of chemical structure and surface properties of synthetic polymers on the coagulation of blood. III. In vivo adsorption of proteins on polymer surfaces. Transactions of the American Society for Artificial Internal Organs 1974;20:474-9.

29 Cottonaro CN, Roohk HV, Shimizu G, et al. Quantitation and characterisation of competitive protein binding to polymers. Transactions of the American Society for Artificial Internal Organs 1981;27:391-5.

30 Vaudaux PE, Waldvogel FA, Morgenthaller JJ, et al. Absorption of fibronectin onto polymethylmethacrylate and promotion of Staphylococcus aureus adherence. Infec Immun 1984;45:768-74.

31 Weathersby PK, Horbett TA, Hoffman AS. A new method for the analysis of the adsorbed plasma protein layer on biomaterial surfaces. Transactions of the American Society for Artificial Internal Organs 1976;22;242-51.

32 Anderson JM, Bonfield TL, Ziats NP. Protein adsorption and cellular adhesion on biomedical polymers. Int $\mathcal{F}$ Artif Organs 1990;13:375-82.

33 Espersen F, Wilkinson BJ, Gahrn-Hansen B, et al. Attachment of staphylococci to silicone catheters in vitro. APMIS 1990;98:471-8.

34 Pascual A, Fleer A, Westerdaal NAL, et al. Modulation of adherence of coagulase-negative staphylococci to Teflon adherence of coagulase-negative staphylococci to Tefor
catheters in vitro. Eur f Clin Microbiol 1986;5:515-22.

35 Herrmann M, Vaudaux PE, Pittet D, et al. Fibronectin, fibrinogen and laminin act as mediators of adherence of clinical staphylococcal isolates to foreign material. $\mathcal{F}$ Infect Dis 1988;158:693-701.

36 Vaudaux PE, Suzuki R, Waldvogel FA, et al. Foreign body infection; role for fibronectin as a ligand for the adherence of Staphylococcus aureus. F Infect Dis 1984;150:546-53.

37 Brydon HL, Hayward R, Harkness W, et al. Reduced bacterial adhesion to hydrocephalus shunt catheters mediated by cerebrospinal fluid proteins. I Neurol Neurosurg Psychiatry 1996;60:671-5. 